\title{
Greening by the market? Distortions caused by fiscal incentives to build on brownfield land.
}

\author{
GWILYM PRYCE
}

Department of Urban Studies, University of Glasgow, Scotland

\begin{abstract}
This is a theoretical paper which draws on the existing land-planning and state failure literatures to underpin its key assumptions and to provide an appropriate context. Its main purpose is to consider the connection between capital markets and brownfield development. The paper begins with a summary of the various explanations put forward for why the private sector appears reluctant to build on brownfield, and offers a previously overlooked possible cause: the impact of asymmetric information on credit markets for residential construction. The paper then moves on to its main focus by considering state failures in the allocation of land and the likely impact of information problems on the success of fiscal measures to encourage brownfield development. As a result, a new form of possible state failure in land use intervention is identified that arises out of the link between fiscal policy and the financial market treatment of brownfield sites. This insight adds to the broader category of research that considers state failures in general.
\end{abstract}




\section{Introduction}

Since the 1992 Earth Summit in Rio de Janeiro, land use planning appears to have reclaimed its primacy as the means of delivering environmental sustainability (Pennington, 2000). "Protection of the environment" and "urban containment" are almost universally assumed to be synonymous and worthy political objectives, and "market allocation" the antithesis of both. This paper reflects on one of the most important aspects of the housing/environmental sustainability debate: that of "brownfield" development, that is, the redevelopment of land in former industrial use. As many UK cities complete their transition from manufacturing to service oriented activity, large areas of wasteland are left redundant and it seems logical that new construction should be encouraged to take place on such sites rather than on "greenfield" plots.

In this paper I consider the variety of explanations put forward for why the private sector appears reluctant to build on brownfield, and I offer a previously overlooked possible cause: the impact of asymmetric information on credit markets for residential construction. The paper also considers state failures in the allocation of land and the likely impact of information problems on the success of fiscal measures to encourage brownfield development. The approach is essentially theoretical, drawing extensively on the existing literature to underpin the key assumptions and provide an appropriate context. Its key contribution is to offer an explanation of how fiscal intervention in the use of land may impact the financial market treatment of brownfield sites. As such, although both the market and state failure literatures are discussed, the focus will be on the latter, largely to provide an appropriate context to the paper's main contribution but also to redress the bias towards intervention in the prevailing 
(particularly policy) discussions. However, it is beyond the remit of the paper to provide an overarching evaluation of market versus state allocation (see Pennington 2000 for a recent example), but I do attempt to contribute to the critiques of both.

The paper is structured as follows: first I draw on existing empirical research to justify my assumption that the market is averse to building on brownfields. Second, I consider the explanations put forward in the literature for this apparent reluctance and I offer a further (complementary) explanation based on capital market distortions. To illustrate this insight I present a simple model of loan applications for land developments with uncertain contamination levels. I then consider the state failure arguments with respect to intervention in land markets that have been highlighted in the existing literature, particularly with respect to the impact of fiscal incentives to building on brownfield. I then identify an additional source of possible state failure that has so far been overlooked, arising from an intuitive extension of the credit market model. Various alternative assumptions are consdiered before the paper concludes with a brief summary.

\section{Market aversion to Brownfields: The Evidence}

In this section I justify the presupposition of the paper that there is an apparent market aversion to building on brownfields. The discussion will provide the necessary backdrop to the following section which will consider the causes of this aversion.

Empirical studies by Bramley (1993a,b) and Pryce (1999a) have considered the impact on new construction of the proportion of new development on brownfield land (which can reasonably be taken as a reflection of local authority land release policy). 
Table 1 shows Pryce's (1999a) estimates of the responsiveness of new construction to the prevalence of brownfield. All of the regression coefficient estimates (row one of the data in Table 1) are negative, suggesting that, in both boom and bust periods, the effect of brownfield development is to reduce new construction overall. As one might expect, both the magnitude of the coefficient and its statistical significance (measured by the $t$ ratio estimates in data row two of Table 1) is stronger during periods of low demand (when the construction sector is booming, firms are less picky about where they locate and the brownfield effect is less statistically significant). From these slope coefficients, Pryce has estimated the proportional effect on new construction of an increase in the incidence of brownfield development (third row of the data). For every $1 \%$ increase the proportion of development on recycled land, new construction overall is found to fall by $0.3 \%$ during boom periods, and by $0.9 \%$ during slumps, equivalent to a decline in construction of around $0.6 \%$ across both periods. 
Table 1

\section{Responsiveness of New Construction to the Prevalence of Brownfield Development}

\begin{tabular}{lcccccc}
\hline Regression type $\rightarrow$ & $\begin{array}{c}\text { Linear* } \\
\text { Supply } \\
\text { Curve }\end{array}$ & $\begin{array}{c}\text { Backward } \\
\text { Bending } \\
\text { Supply } \\
\text { Curve }\end{array}$ & $\begin{array}{c}\text { Linear* } \\
\text { Supply } \\
\text { Curve }\end{array}$ & $\begin{array}{c}\text { Backward } \\
\text { Bending } \\
\text { Supply } \\
\text { Curve }\end{array}$ & $\begin{array}{c}\text { Linear* } \\
\text { Supply } \\
\text { Curve }\end{array}$ & $\begin{array}{c}\text { Backward } \\
\text { Bending } \\
\text { Supply } \\
\text { Curve }\end{array}$ \\
\hline Period & $\begin{array}{c}\text { Boom } \\
(1988)\end{array}$ & $\begin{array}{c}\text { Boom } \\
(1988)\end{array}$ & $\begin{array}{c}\text { Slump } \\
(1992)\end{array}$ & $\begin{array}{c}\text { Slump } \\
(1992)\end{array}$ & $\begin{array}{c}\text { Pooled } \\
(1988+\end{array}$ & $\begin{array}{c}\text { Pooled } \\
(1988+\end{array}$ \\
& -1.45 & -2.09 & -2.68 & -2.68 & -1.64 & -1.68 \\
$\begin{array}{l}\text { Regression coefficient on } \\
\text { \% of residential } \\
\text { development on land in } \\
\text { former urban uses }\end{array}$ & & & & & & \\
$\begin{array}{l}\text { t value (corrected for } \\
\text { heteroscedasticity) }\end{array}$ & $(-0.59)$ & $(-0.86)$ & $(-2.44)$ & $(-2.42)$ & $(-0.92)$ & $(-0.95)$ \\
$\begin{array}{l}\text { Impact on new } \\
\text { construction of a 1\% } \\
\text { increase in the proportion } \\
\text { of brownfield } \\
\text { development* }\end{array}$ & $-0.24 \%$ & $-0.34 \%$ & $-0.90 \%$ & $-0.90 \%$ & $-0.61 \%$ & $-0.62 \%$ \\
\hline
\end{tabular}

$*$ i.e. linear in house price

** this is termed 'the elasticity of supply with respect to brownfield development' Source: Pryce's (1999a) simultaneous equation model of new construction

The implication of these results is that the impact of constraining new development (either through quotas or fiscal incentives) to brownfield sites in an attempt to prevent urban sprawl may reduce the overall level of new construction. If this proves to be the outcome of such policy measures over the next ten years, when the demand for housing is anticipated to rise significantly (projections in 1999 suggested a $19 \%$ increase in the number of households over the period 1996-2021; KPMG 1999), then there could be a substantial shortfall of supply and increases in house prices and homelessness as a result (see Quigley and Raphael 2001 and Kemp et al 2001 for the link between homelessness and wider economic/housing market conditions in the US and the UK respectively). Such estimates should be of particular concern in the UK where housing supply is already highly unresponsive to house price appreciation 
(Pryce 1999a estimates that for every $10 \%$ rise in house prices, new construction supply in England could rise by as little as 6\%, holding everything else - including the prevalence of brownfield -- constant).

There will be further discussion of these issues in the second half of the paper when we turn our attention to government failure in land use intervention, but first we need to consider why there is an apparent reluctance to build on brownfield.

\section{Market aversion to Brownfields: Explanations}

\section{Demand-Side Factors}

If society is genuinely averse to urban sprawl, this should be reflected in demand for developments on recycled land, the profitability of such developments and ultimately in supply. The truth is that housing demand data belie society's commitment to urban containment. Consider the population trends listed in Table 2. These population movement data strongly suggest that the long term trend in housing demand is counter-urban. Areas which have experienced the greatest gain in population have been those furthest down the urban hierarchy, such as "remote, mainly rural" and "resort, port and retirement districts" and those with the greatest population loss have been areas such as the "principal cities" and Inner London (KPMG 1999, p.19). Thus, one cause of the market's apparent reluctance to build on brownfields emanates from the demand side - developer are simply following consumer's preferences. ${ }^{1}$

${ }^{1}$ A question arises here regarding the mismatch between the public preferences as presented in the media that suggest a desire to protect greenfields, and the preferences replicated in actual housing demand decisions. One explanation for the paradox is to think of it as a conflict between private costs/benefits and public costs/benefits. The argument is typified in Garrett Hardin's (1968) classic environmentalist essay, "The 


\begin{tabular}{lc}
\hline Area & $\begin{array}{c}\text { \% Change in Population } \\
(1981-1991)\end{array}$ \\
\hline Metropolitan, principal cities & -7.4 \\
Inner London & -5.1 \\
Metropolitan, other & -4.2 \\
Outer London & -4.1 \\
Large cities, non metropolitan & -3.6 \\
Resort, port and retirement & 5.2 \\
New Towns & 6.1 \\
Remote, mainly rural & 6.4 \\
\hline
\end{tabular}

Source: OPCS, Regional Trends No.32, quoted in KPMG (1999)

Supply side considerations - the role of uncertainty

In addition to demand side factors, there are a number of complementary influences from the supply-side related to the nature of the development process and its associated risks and returns. These tend to be either institutional (as in Adams et al, 2001) or informational. The two are not mutually exclusive, of course, and the latter is often cited (as in Adams et al 2001) as a subset of the former, but it is very much the latter which forms the focus of the remainder of the paper.

Tragedy of the Commons". Speaking of a "pasture open to all", each herdsman will rationally conclude that, "the only sensible course for him to pursue" will be to successively add further animals to his herd. Though it is collectively is beneficial to limit consumption of a common resource (whether it be fish stocks, greenbelt, clean air, tranquillity, or country views), without such controls, common resources are rapidly depleted to the detriment of all. So, although there may be net costs to society of urban sprawl, the cost/benefit calculation may be unambiguously positive for both the individual facing the opportunity to relocate on the edge of the city, and for the individual developer facing relatively trouble free construction and agricultural land prices. As a result, "Freedom in a commons brings ruin to all" (Hardin, 1968, p.144). 
I shall consider two subsets of information failure: those arising due to uncertainty (i.e. lack of information available to all parties), and those arising from asymmetric information (i.e. more information available to one party than another). The first class of information failure relates to the factors that lead to unpredictable variation in either the costs or returns associated with brownfield development. Given that "financial decisions are generally based upon the tradeoff between risk and return" (Engle, 2001, p.167), if the uncertainties faced by developers regarding brownfield development are greater than greenfield, but the returns to brownfield development are not correspondingly greater, market players will always have a propensity to opt for greenfield development (all other things being equal).

The second category of information failure that I discuss here has not been considered in the existing literature on brownfield development and as such adds to existing critiques of market allocation. It refers to the impact of property development information asymmetries on the capital market, and in particular, scenarios that lead to developers having incentives not to reveal adverse information about a potential development project, or that lead to more risky developers applying for funds. In either case, if lenders/investors are in any way less well informed than developers about the investment risks, then (as I shall argue later) not only will the market development of brownfields be constrained, but also fiscal intervention to remedy the inertia will be frustrated. Before we consider the state failure implications of asymmetric information, let us look at the effect in the market context of these two categories of information failure. 


\section{The Role of Uncertainty}

Titman (1985) argues that holding land vacant can be a valuable option because it permits the developer to wait until some of the uncertainty regarding future states of the world is resolved, and this is particularly valuable in the construction industry where, once a firm has committed itself to a programme of development, it is very difficult to reverse direction. Development controls increase the uncertainty surrounding future courses of action, and reinforces the value of holding land vacant, to the extent that it may actually exceed the value of developed land. This has the important corollary that 'housing will not be supplied if the value of the land exceeds the value if developed" (Mayo and Sheppard 1991, p. 6). Thus, "an increase in the variance of planning delay, holding the expected duration of delay constant, will increase the value of vacant land and decrease the supply of housing in the current period." (Mayo and Sheppard, 1991, p.12).

Although neither Titman nor Mayo and Sheppard explicitly consider the impact of their models for brownfield/greenfield development, the findings of these papers do have implications for developers' propensity to build on recycled land. In particular, Mayo and Sheppard find that, the greater the level of uncertainty due to factors such as development controls, the lower the cut off price at which supply becomes backward bending. If uncertainty associated with brownfield development is for any reason greater than that for greenfield, the corollary is that there will be a more adverse supply response with regard to the former.

What reasons might there be for greater uncertainty to exist with regard to the development of former industrial land over other types of development? First, there 
are a set of uncertainties associated with contamination (Bond et al, 2001). Rodenburg et al (2000), Weber (1997) and others have detailed the huge complexities associated with the contamination process which arise from the unique interaction of scientific (soil toxicity etc.), economic, social, logistic, legal and political factors. The true extent of contamination (and hence the true cost of decontamination) is usually unknown even following a survey.

This is because, "there are few appraisers with training adequate to place a value on a contaminated property 'as is"” (Weber, 1997, p. 379). Surveyors can only attempt an estimate of the probability and prevalence of contamination (by taking intermittent soil borings, for example). And the greater the level of contamination, the greater the uncertainty regarding the cost of cleaning due to fundamental non-linearities in the local eco-system. Once the threshold levels of toxicity have been reached, there is a much greater chance of knock on effects on other aspects of the environment (Patchin, 1988 and Weber, 1997, for example, note that there is a chance that soil contamination will seep onto another owner's property). There is also a greater chance that the decontamination process itself may have adverse effects, either as a direct effect of the cleaning process, or as a result of the stigma attached to a site once it has been found to be contaminated (Weber, 1997; Bond 2001a,b).

A second category of uncertainty relates to the systemic risks that arise from contiguous development contingencies. Whether a homeowner purchases a house in the city or in the country, she will face the risk that 
at some point in the future, the use of adjacent land will change in a way that reduces her neighbourhood satisfaction and/or adversely affects the market value of her dwelling. A comparable derived risk will be faced by the developer. Adverse contiguous developments during the construction process (or adverse changes in expected future outcomes) may result in a fall in demand. However, the urban developer faces a unique and additional risk, particularly when the plot of land he/she seeks to develop is part of a much larger brownfield area. Here the success or failure of the development may be contingent on the success or failure of simultaneous developments on contiguous plots. Hence the brownfield developer faces a degree of systemic risk unfamiliar to the greefield developments where the surrounding areas are (at least initially) by default a positive selling feature.

A third set of uncertainties facing brownfield developers are those associated with policy response. There is, at least in the UK, an increasing plethora of grants, special programmes and divisions of government relating to brownfield development. The range and structure of these subsidies is broad, ad hoc, complex, and increasingly crucial to the decision of whether or not development goes ahead. Adams et al (1999) find that, 'brownfield redevelopment is increasingly driven by the availability of development grants and subsidies' (Adams et al, 1999, p. 2, see discussion below). Thus, government policy itself is a source of uncertainty, particularly with regard to whether there will be a more favourable set of subsidies a some point in the future and whether it would therefore be better to delay development. As a result, political 
complexities and uncertainties have a similar adverse impact on the supply of new construction (in this case, brownfield construction) to what Mayo and Sheppard (1991) call "stochastic development control".

\section{The Role of Asymmetric Information and Credit Rationing}

A crucial element to the development process is that of financial capital (Ball et al, 1998) and yet the cause, prevalence and impact of credit rationing in the financing of real estate and residential development has largely been overlooked. This is not so in the wider economics literature. Credit rationing has, for example, been suggested as a key driver of episodes such as the Great Depression, when 'developments in credit markets seem to have amplified output fluctuations' (Baachetta and Caminal, 1996, p.1; see also Bernanke, 1983). The importance of credit rationing can be seen by considering the nature of economic behaviour in its absence - when access to credit is unfettered, households will be able to sustain consumption levels (and firms maintain investment), even during periods of low income (profit). This has the knock on-effect of smoothing-out fluctuations in income (output) throughout the business cycle. But if credit rationing is prevalent, the ability to subsidise the bad years with good is limited, and output volatility is inevitably exacerbated. Lenders ration credit by placing ceilings on the size of loans rather than altering the price of loans (hence, the apparent inertia of interest rates during significant shifts of the demand and supply for funds; Stiglitz and Weiss 1981; Stiglitz, 1999). For a more comprehensive review of the credit rationing literature see Pryce (1999b). 


\section{A Simple Model}

To illustrate the implications for credit rationing of asymmetric information in land development consider a simple model where there are two types of land development: $i=g, b$ where $g$ indicates development on land perceived to have low levels of contamination and $b$ denotes development on recycled land perceived to have high levels of contamination (alternatively, this could be interpreted as two types of developer: one who always builds on greenfield or low contamination land and one who always builds on brownfield or high contamination land). Assume that banks cannot distinguish between $g$ and $b$ (the model could be extended to include many categories of risk, and the assumption would then be that there are at least two risk categories which the lender cannot distinguish between and to whom the lender has to charge a pooled interest rate). Developers require fixed amount of capital $K$ to purchase and develop the land. Now assume that the more contaminated a plot of land, the greater the estimated costs of decontamination $D^{c}{ }_{\mathrm{i}}$ and the greater the uncertainty associated with that estimate. If the estimate is correct (with probability $p_{i}$ ) then the project receives a common return $R$. For simplicity it is assumed that greater perceived decontamination costs are exactly offset by lower land prices. However, there is a probability $\left(1-p_{i}\right)$ that the actual decontamination costs do not equal $D_{i}^{c}$ but are substantially greater, resulting in zero net return.

Note that although contamination is not the only source of risk facing developers, it is one that varies most obviously between brownfield and greenfield sites and so it is one that has a clear effect on the choice to build on brownfield or greenfield. It is also the risk which will have a bearing on the outcome of any form of fiscal intervention which discriminates development on the basis of whether it is brownfield or 
greenfield development. It is therefore the risk we need to focus on here by holding all other risks constant. Although other risks, such as those on the demand-side, might offset contamination risks (a Thames side brownfield development might be less 'risky' overall than a greenfield development in Newcastle), incorporation of them into the model would add little to its efficacy, since we would still want to know what would be the impact of different anticipated levels of contamination within areas of similar levels of demand (what makes a developer more or less likely to build on a greefield Newcastle site as opposed to a brownfield Newcastle site?). So although the range of risks considered by the model is limited, this will be seen to be appropriate when one applies ‘Ockam's Razor'.

A further potential criticism of the model is the observation that lenders can draw on expert appraisers to identify the risk of contamination. This observation is of course true in many situations, though one should be aware that substantial land developments funds can be raised in capital markets with very little specification or limitation as to how those funds will be used (corporate loans, for example, are issued on the back of the corporate entity rather than a specific project; Cadman and Topping 1995 p. 150; Ball et al, 1998).

Note that even when appraisers are employed, their assessment does not remove risk: they can only give an estimate of the risk of contamination and of the costs involved in removing it. Such estimates are subject to random error, which inevitably increases with the anticipated level of contamination due to the associated burgeoning potential for complex, unforseeable interactions with the local ecosystem (see Bond et al 2001; Bond 2001a,b; Rodenburg et al 2000; Patchin 1980; and Weber 1997 on the 
difficulties of appraising contaminated land). Such intrinsic non-linearities mean that there is always a chance (denoted above by $1-p_{i}$ ) that actual contamination costs significantly exceed estimates, and as assumed in the model, $1-p_{i}$ will rise as anticipated contamination rises.

Note further that if developers have private information that would improve the accuracy of the contamination survey, there may be no incentive for them to reveal that information. Moreover, the developer may choose to have a much more extensive and informed survey than the lender or may have access to previous surveys or insider information of which the lender is not aware. As such, there is a fundamental asymmetry of information, the corollary of which is that amongst projects given a similar estimated probability of contamination by appraisers, lenders know that even with this expert appraisal they are still pooling potentially a wide range of actual decontamination costs. Developers' private knowledge may therefore allow them to identify a project as having a much higher chance $\left(1-p_{b}\right)$ that actual contamination costs will significantly exceed estimates, than that revealed to the lender by the appraiser $\left(1-p_{g}\right.$, where $\left.p_{g}>p_{b}\right)$. But how will this private knowledge affect their choice of project?

Given the above assumptions, borrower expected profits will be as follows:

$$
\prod_{i}=p_{i}(R-(1+r) K)-\left(1-p_{i}\right) C+\left(1-p_{i}\right)(0)
$$

where $C$ is collateral. For an offer of a loan to be accepted, the developer requires that $\prod_{i} \geq 0$. This implies that, the return if successful has to be greater than the amount that has to be repaid,

$$
\mathrm{R}>(1+r) K
$$


which is the necessary condition for a risk neutral developer to go ahead with a project. Because both $g$ and $b$ developments receive the same returns, $g$ will be preferred to $b$ because of the greater certainty regarding estimated decontamination costs: $p_{g}>p_{b}$ implies $\prod_{g}>\prod_{b}$ when there is a common return, $R$, to development. (If we were to allow the returns to vary by a random component with the same distribution for both types of development, then sometimes $b$ development would be more profitable, and sometimes $g$ would be more profitable, but the returns would still be the same on average; therefore, on average, less contaminated development would still be more profitable because of the lower risk of excessive contamination costs).

The sufficient condition for the developer to accept a loan offer is derived by solving [1] for $p_{i}$, which gives,

$$
p_{i} \geq p_{\#}
$$

where,

$$
p_{\#}=C /(R-(1+r) K+C) \text {. }
$$

This suggests that for a given $R, r, K$ and $C$, there is some threshold probability of success, $p_{\#}$, below which it is not worth going ahead with the project. This implies three possibilities: (i) $p_{b}<p_{g}<p_{\#}$, where neither project will be worthwhile; (ii) $p_{b}<$ $p_{\#}<p_{g}$, which suggests that only the low risk project will be accepted; (iii) $p_{\#}<p_{b}<$ $p_{g}$ and so both projects are worthwhile. A less restrictive outcome is reached if we allow for many projects of both types and a range of probabilities, with the assumption that the mean probability of correctly perceived contamination costs is greater for projects with lower levels of perceived contamination. This would mean that if the distributions of both sets of probability have a similar shape, then a greater proportion of greenfield projects will be worth funding than brownfield projects. 
Notice, however, that a rise in the rate of interest $r$ (to clear the market during a period of excess demand, for example) does not adversely affect one type of developer any more than the other: $p_{\#}$ is the same for both types of development because $R$ is the same (along with the other right hand side variables in equation [4]). Therefore, no moral hazard problem is incurred by raising the rate of interest, and there is no equilibrium credit rationing of the type described by Stiglitz and Weiss (1981). Should, however, there be greater return associated with the greater risk of brownfield development, then developers will have an incentive not to fully reveal adverse information about the risk of a particular brownfield development, and Stiglitz and Weiss credit rationing would be a possibility. ${ }^{2}$

Thus, we have an additional and complementary explanation for why the private sector may be reluctant to build on brownfield land. If the greater risk associated with brownfield development is not matched by more handsome returns, then borrowers will prefer greenfield development since the cost of borrowing will be at least as expensive if they opt for brownfields. On the other hand, if higher returns are associated with the higher risk, there will be a "moral hazard" effect - developers will have an incentive not to reveal the true risks of brownfield development. In this scenario, lenders will either ration credit to all residential projects (resulting in a

\footnotetext{
${ }^{2}$ An anonymous referee commented that it would perhaps be more appropriate to model the land development loan market in a way that incorporated risk assessment and risk pricing. Note, however, that credit rationing could occur even where there is risk assessment and price discrimination provided there is some degree of risk pooling and as long as there is a positive relationship between risk and return (Pryce 1999b). Pooling will occur if lenders do not have perfect knowledge about borrower and project risks but have to group borrowers into broad categories of risk. Such pooling is characteristic of the great majority of credit markets, evidenced by the prevalence of interest rate bands, rather than a continuum of risk premia computed separately and precisely for each and every loan application. Within such interest rate bands there are almost inevitably a spectrum of actual risks and thus the potential of Stiglitz and Weiss credit rationing remains (Pryce 1999b Chapter 5).
} 
deleterious effect on the supply of new houses) or they will find methods of screening out brownfield development. Either way, the capital market can be seen as a constraining influence on brownfield development.

\section{State Failures Identified in the Existing Literature}

Over the decade since the 1992 Earth Summit, market failures rather than government failures have tended to dominate the discussion of land allocation. Though the renaissance in urban living may have been one more of hope than substance, the same cannot be said of the penetration of state intervention in land markets. This is generally taken to be inevitable, if not desirable. There has been a renaissance, if not in urban living, then in enthusiasm for state intervention in land markets (Pennington 2000).

A number of academics (Evans 1985, 1987, 1988, 1991, 1996; Chesire and Sheppard 1989, 1997; Pennington (1997a, 1997b, 1999, 2000, inter alia) have nonetheless continued to proffer a well-argued case for taking seriously the failures of land use planning and the need for greater market involvement. Markets, it is contended, suffer from information problems, but then so do planners. Indeed, there may be "no way for planners to obtain the information that would be necessary to 'correct' for market 'inefficiencies"' and so "markets may well be 'imperfect' institutions but they may still offer important advantages over the governmental alternative" (Pennington 2000, p. 7, surveying the Austrian and Virginia schools of public choice theory). State allocation is also vulnerable to "collective action problems", such as rent seeking, where "the construction industry and local residents associations may, for example, have sufficient incentive to lobby for planning policies ... that will 
concentrate benefits on their relatively few members" (Pennington 2000, p. 13). The restrictive planning policies that result have a particularly deleterious effect on the welfare of those at the lower end of the income scale, not only by driving house prices up and thus excluding those with less disposable income, but also by dampening the benefits of the so-called 'filtering effect':

'The more new houses that are built (even if many of these are at the 'top end' of the market), the more used housing becomes available and the more the relative price of housing will fall." (Pennington, 2000, p. 43)

Pennington's argument is that land-use planning policies in the UK have severely dampened the quantity of new build (cf the UK's comparatively low levels of housing starts per capita ${ }^{3}$ in Figure 1) and as a result, "slowed down the filtering process by which affluent homes reach the lower income groups" (Pennington, 2000, p. 43). Low levels of housing supply also exacerbate overcrowding and homelessness.

In addition to these general failures of intervention in land markets, there are perverse effects specific to brownfield development. It is to these that I now turn.

\footnotetext{
${ }^{3}$ The data in Figure 1 do not in themselves imply state failure through planning. The other countries compared may, for example, have geographical or demographic circumstances that are the true causes of the difference in per capita new-build. Even so, the graph is revealing because it highlights the problem that the UK faces with regard to housing supply, and the fact that the planning system has failed to avert the downward trend in per capita supply.
} 
Figure 1

\section{Housing Starts per Capita}

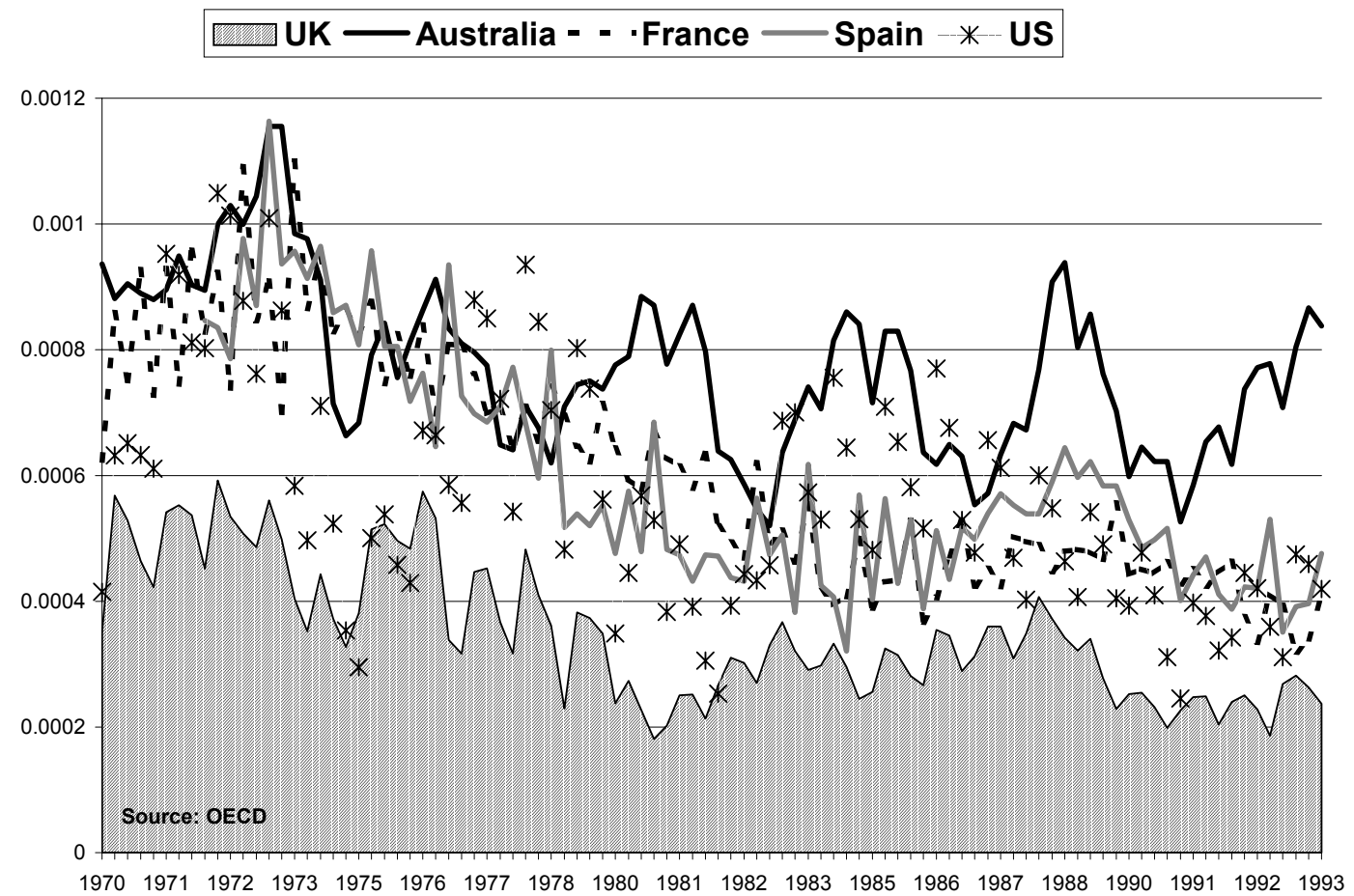

State Failures in Urban Land Development

There are two main categories of government failure with regard to the redevelopment of urban land that have been highlighted in the literature. The first, which has already been discussed above in the context of market failure, relates to the lack of knowledge facing developers regarding future planning policies which may exacerbate reluctance the market's reluctance to build on brownfield (see, for example, Mayo and Sheppard 1991). Thus, an important source of market failure may have its origin (at least in part) in the nature of intervention itself. 
The second, to be considered below, is a corollary of two the aforementioned sources of government failure; namely inelasticities in supply (caused by the uncertainties exacerbated by public policy and/or by the direct constraints of land use planning) that diminish the impact of fiscal interventions (as argued by Needham, 2000). In the penultimate section of the paper I shall add a third potential source of state failure which arises out of the distortionary effects of fiscal intervention in the use of land on the capital market treatment of brownfield investment.

\section{The Effect of Inelasticity on the Success of Fiscal Intervention}

Classical economists such as Ricardo and Mill were of the view that land taxes had no effect on the price or quantity of land, or on agricultural output or price (Needham, 2000, p.224). As neoclassical economists later went on to demonstrate, however, this argument rested on the premis that the ratio of the proportional change in quantity supplied to the proportional change in price is zero. In other words, supply is totally unresponsive to changes in price (or in the parlance of economists, "perfectly inelastic”). The assumptions underlying this result are that all land is taxed equally, that the economy comprises of one industry, and that as a result there are no substitution effects.

Should these assumptions fail to hold, then there is the possibility that a tax or levy on one sort of land will result in changes in the price and use of other land types. Both suppliers and consumers may substitute the untaxed land for the land that is taxed. For example, if the tax causes the price of land to rise, "the demander might switch a part of his/her demand for the taxed land (e.g. building land on greenfield sites) to 
another sort of land which is untaxed (e.g. building land on brownfield sites), because the relative prices of sorts of land have changed." (Needham, 2000, p. 248).

The extent of this effect will crucially rest on how responsive demand and supply are to price. This responsiveness is traditionally measured in terms of elasticities which measure the percentage change in quantity demand (supplied) due to a percentage change in price. Taxation of land as a means of affecting land use will be effective if and only if (1) the price elasticity of supply is high (that is, responsive to price) for the land being taxed; (2) the price elasticity of demand is also high (responsive to price) for the price of land being taxed (Needham 2000, p. 249). The first of these conditions is unlikely to apply in the UK, however, since estimates of the price elasticity of supply have generally been less than one, as shown in Table 3. (The figures in Table 3 show the effect of a percentage change in supply of a one percent rise in price. A price elasticity of supply of 0.4 thus indicates that the quantity of new build only rises by $0.4 \%$ if house prices rise by $1 \%$, all other things being equal; see Bartlett, 1989, for a comprehensive, if rather, dated review of housing supply elasticity theory and estimation). 
Table 3 Estimates of the Price Elasticity of Supply ${ }^{*}$ of New Construction

\begin{tabular}{lc}
\hline Study & PES $^{*}$ \\
\hline Whitehead (1974) & 0.5 \\
Mayes (1979) & 0.3 (Short Run) \\
& 0.6 (Long Run) \\
Bramley (1996) & 0.8 \\
Meen (1998) & 0.4 \\
Pryce (1999a) & 0.6 (boom) \\
& 1.0 (slump) \\
\hline $\begin{array}{l}\text { * Price Elasticity of Supply }=\% \text { change in supply } \\
\text { of new build due to a 1\% rise in price }\end{array}$
\end{tabular}

With regard to Needham's second condition for effective land use taxation (that demand is inelastic), because land is a factor of production, its demand is a derived demand and Hicks' "four rules of derived demand" hold (see Needham 2000, p. 247; Sirmans and Redman, 1979). These "rules" state that, the price elasticity of demand is higher: (a) the higher is the price elasticity of demand for the product; (b) the bigger the share of the costs of the factor in total production costs; (c) the easier it is to substitute other production factors for the one factor; and (d) the bigger the supply elasticity of the substitutable factors. Although rule (b) has a positive outcome for land (land usually constitutes a significant proportion of production costs), rule (c) does not bode well for the elasticity of demand for land since it is not easy to substitute other production factors, particularly since high rise living is not in fashion. Furthermore, as Table 4 shows estimates of the price elasticity of demand unfortunately tend to be no greater in magnitude than those of supply (for examples of earlier work on housing demand see Muth 1960, 1964, 1969, 1971; Bradbury et al 
1977, and Olsen 1987). Most estimates of the price elasticity of demand value it at significantly less than one (so a $1 \%$ change in price will result in a less than $1 \%$ change in quantity demanded).

\section{Table 4 Estimates of the Price Elasticity of Demand* for Housing}

\begin{tabular}{lc}
\hline Study & PED $^{*}$ \\
\hline King (1980) & -0.7 \\
Ermisch et al (1996) & -0.4 \\
Pryce (2001) & -0.5 (boom) \\
& -0.1 (slump) \\
\hline Price Elasticity of Demand $=\%$ change in the \\
demand for new build due to a $1 \%$ rise in price
\end{tabular}

Basing his calculations on supply and demand elasticities similar to those of the UK, Needham (2000, p. 254-255) estimates for the Netherlands, "how high the tax on noncontaminated land would have to be in order to remove its cost advantage relative to contaminated land" (Needham 2000, p. 254). He finds that a tax of $f 730000$ per ha on non-contaminated land would be necessary in order to make the land price rise from $f 300000$ to $f 508500$ per ha. "This," he concludes, "is ... absurd. Clearly, [the owner] will withdraw his/her supply" (Needham, 2000, p. 254). The state could use other measures to affect land use, such as restricting the supply of housing land by tightening planning controls, but "then a very high price is being paid to achieve the planning aim of getting contaminated land back into use: the supply of housing is being severely restricted and house prices pushed up. It would be better to subsidise the costs of decontaminating the land" (Needham, 2000, p.255). 
Needham's conclusions are supported to some extent by recent qualitative work by Adams et al (1999). Based on an analysis of 20 development sites in each of the four UK cities: Nottingham, Stoke, Aberdeen and Dundee, they find that, 'brownfield redevelopment is increasingly driven by the availabilty of development grants and subsidies' and that, 'relatively few owners were influenced by any threat that the state might unduly tax them for keeping land vacant or obsolete' (Adams et al, 1999, p.2). That construction is highly cyclical (most construction takes place during boom periods - see Figure 2) and that the price elasticity of demand for housing is likely to be greatest (in absolute terms) during booms (Table 4, Pryce 2001), does nothing to mitigate the anticipated impotence of land use taxation, because the increase in responsiveness of demand during an upswing happens to be almost exactly offset by the falling responsiveness of supply (Table 3, Pryce 1999a).

Figure 2

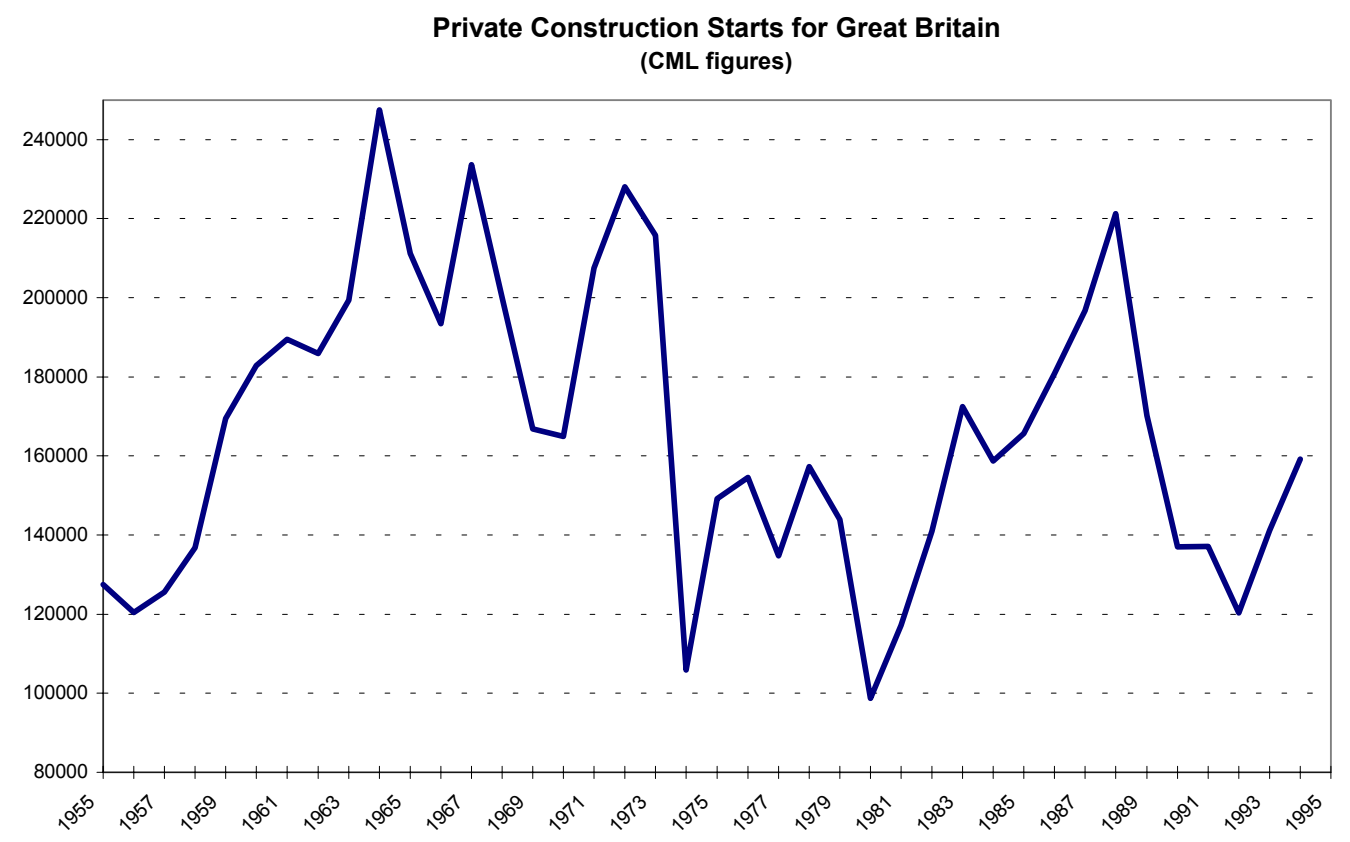




\section{State Induced Distortions to Loan Markets}

We noted that the asymmetry of information in credit markets may not only be an exacerbator of low supply response, but also of the reluctance to build on brownfield. What I propose to show in this section is that the introduction of fiscal advantages to brownfield may actually increase the negative effect of credit markets on both these aspects of supply, and that even Needham's (2000) solution of subsidising decontamination may not avert perverse incentives if these subsidies are flat rate.

Consider the simple model developed earlier. Suppose now that a tax concession or subsidy to brownfield development is introduced which encourages construction on land with higher levels of contamination. This concession results in two different levels of return $R_{g}$ and $R_{b}$, to low and high contamination development respectively, where $R_{g}<R_{b}$. Borrowers only go ahead with development if $R_{i}<(1+r) K$. Let $R_{i \#}$ be the minimum level of return necessary to induce $i$ to invest, where $R_{i \#}=(1+r) K$. It can be seen that $R_{i}^{\#}$ is positively related to $r$ : the higher the interest rate, the greater the return necessary to make investment worthwhile.

Notice, however, that higher risk developers now receive a higher level of return if successful and so would be willing to invest at higher rates of loan interest than greenfield developers. Now that there is a negative relationship between $R_{i}$ and $p_{i}$ (because $p_{g}>p_{b}$ and $R_{g}<R_{b}$ ) it is possible to define the development decision in terms of a heterogeneous threshold level of success probability, $p_{i \#}$ above which it will not be worthwhile for the developer to go ahead with the project. $p_{i \#}$ is determined where the borrower just breaks even $\left(\prod_{i}=0\right)$ which gives:

$$
p_{i \#}=C /\left(R_{i \#}-(1+r) K+C\right)
$$


It can be seen from [5] that $p_{i \#}$ is strictly decreasing in $r$, and so a rise in interest rates may screen out low risk development. For example, let $r_{1}$ be the initial rate of interest, such that: $p_{1}^{\#}\left(r_{l}\right)<p_{b}<p_{g}$. Now suppose that there is an outward shift in demand for new construction which feeds through to an expansion of the number of loan applications from both types of land. In order to clear the market, banks would have to raise the interest rate from $r_{1}$ to $r_{2}$ where $p_{1}^{\#}\left(r_{2}\right)>p_{1}^{\#}\left(r_{1}\right)$ and $p_{b}<p_{2}{ }^{\#}\left(r_{2}\right)<p_{g}$. In other words, it is no longer worthwhile for developers to progress with projects on low risk land because the cost of repaying the loan plus interest now exceeds the profits received even when the project is successful. Consequently, there is adverse selection - lenders only receive requests for loans for high risk development which still have rates of return sufficiently high to cover loan plus interest and make a profit.

This effect could alternatively be given a "moral hazard" interpretation if we assume that each developer has the option to choose between project types. In this case, borrowers have an incentive not to reveal to lenders the true risks of their development so that they can receive the same pooled interest rate offered on low risk projects. Whether interpreted as "adverse selection" or "moral hazard", the effect may be to induce equilibrium credit rationing, which is defined as the situation where it is not in the lenders best interests to raise the rate of interest from $r_{1}$ to $r_{2}$ even when the number of loans demanded at $r_{l}$ is greater than the number of loans supplied: $\mathrm{N}_{\mathrm{i}}^{\mathrm{D}}$ $>\mathrm{N}_{\mathrm{i}}$. Effectively, a situation arises where the adverse effects on the quality of the lender's loan portfolio outweighs any short term gain from charging higher interest rates. Note that this possibility arises under any circumstance where the developer has more information regarding the risks of the development project than the lender. Informal conversations with property development lenders confirm that this is indeed 
a concern for them. Developers have a clear incentive to conceal from lenders negative information on the apparent riskiness of the development.

The broader implication of this result is that any government intervention which is known to increase the profitability of high risk investment relative to low risk investment, will inflate the incentive for developers to conceal risk and raise the likelihood that lenders ration credit. By reinforcing the positive relationship between risk and return, the state is, in effect, exacerbating the moral hazards already endemic in most credit markets (we have so far assumed that before government intervention, higher risk projects had the same return as lower risk projects, but this may not be the case, and so some degree of moral hazard is likely to exist even before intervention because of the general tendency for higher risk projects to have a higher return if successful). If lenders are unable to anticipate the precise use of loaned funds, then situations will arise where they will prefer to ration credit to all borrowers rather than raise the rate of interest.

In response, lenders may put limits on lending as a whole, or may ration credit to projects of certain types. That this already exists is widely recognised (though see Parker, 2002, for an alternative view). A survey of lenders by Kinnard (1996), for example, found that $35.6 \%$ of lenders and $25 \%$ of investors were found to avoid property with known soil contamination, and that $45.8 \%$ of lenders and $41.1 \%$ of investors avoid property with known groundwater contamination. The danger is that fiscal intervention, in inflating the relative returns on brownfield development without ameliorating any of the risks, will 
give developers a greater incentive not to reveal to lenders their true knowledge of the risk of development, forcing lenders to tighten their credit rationing restrictions.

The magnitude of the effect of state-induced credit rationing (an example of the state causing or exacerbating market failure) on the supply of new construction will of course depend on the proportion of all potential new construction projects that require debt financing. If a large proportion of new construction projects require loans, then the impact could be far reaching. Although an increase in credit rationing in the real estate sector will contribute to the effect of credit rationing in the economy as a whole, the most potent effect may come via the supply of housing and its disproportionate influence on the rest of the economy. Subsidies or tax concessions to brownfield development may mean that, during times when new construction is most needed (i.e. during boom periods), funds for new development will be more difficult to obtain than if there had been no government intervention. If supply is already inelastic (which appears to be the case in the UK - see Table 3), then the adjustment of prices back to their long run levels may well be too slow to allow supply to ever respond adequately within the given policy and cyclical time-frame. The result is that prices are largely demand-driven and highly cyclical. This has implications for the macro-economy via the impact of house price booms and equity withdrawal on the consumption function (see Carruth and Henley, 1990). The indebtedness caused by equity withdrawal and spiralling mortgages continues into the slump period. Debtoverhang dampens consumption and inhibits labour mobility (through negative equity), thus prolonging the recession and resulting in a deleterious effect on the wider economy (see Maclennan 1994). 


\section{Subsidy as a Signal of Risk}

Suppose that lenders can actually observe whether an investment project will be eligible for tax concession or subsidy. Under this scenario, the state intervention in effect enables banks to distinguish between $b$ and $g$ development types. Where this is the case, the bank will charge separate interest rates to the two groups, and (ceteris paribus) $r_{b}$ will be greater than the initial pooled interest rate:

$$
r_{g}<r<r_{b}
$$

Even if the subsidy acts as a signal, there still remains an unintended adverse consequence of the government intervention since the cost of funds for building on more contaminated land will rise, and this may counteract the subsidy/tax concession incentive. This is particularly true if the tax concession/subsidy is relatively small, because the subsidy acts as a signal to lenders of development type, regardless of the size of the subsidy or tax concession. If the brownfield sites with higher levels of contamination has much higher risk than the low contamination sites, the interest rate charged to the high risk development may be significantly higher due to the signal provided by intervention, and the additional costs may actually result in less brownfield construction on contaminated land.

\section{Brownfield Credit Rationing - An Additional Explanation for Concave Supply?}

Pryce (1999a) posited that the supply of UK housing may rise at a decreasing rate as house prices rise (described by economists as 'concave supply' since such a supply schedule would be concave to the origin - having an " $r$ " shape curve), and may even 'bend backwards' (that is, the curve would be so concave that over a certain range in 
the supply curve, new construction may actually fall as prices rise - depicted by an “n” shape supply curve; see Shea 1993 and Ozanne 1996). Now, the credit rationing argument posited in this paper may constitute an additional cause of concavity in housing supply curves. It is likely that, with or without government subsidy, the attractiveness of building on brownfield land will vary with the economic cycle. During boom periods, land supply constraints (particularly in the UK) may force developers to consider building on more risky land types in order to take advantage of rising house prices. Such cycles, however, are not likely to be uniform across regions, with some regions experiencing house price inflation whilst others are facing deflation. This variation in house price (whether across time or space) is exacerbated by land supply constraints in the face of shifting demand. It may be then, that developers are faced with a choice between building in areas where there an abundance of greenfield land but where house prices are stagnant, or building in on brownfield land in areas where there is house price inflation but a shortage of vacant greenfield land. This results in a choice for developers between low risk, low return projects (greenfield), and high risk, high return development (brownfield). In reality, there is likely to be a continuum of across space of the ratio of returns to brownfield development relative to greenfield development. Assuming that there is a single national credit market, lenders will be faced with problems of moral hazard which arise simply from the spatial coincidence of greenfield shortages and higher returns to development. This will result in a concave relationship between the rate of interest and the return to lenders from extending credit and in the kind of equilibrium credit rationing proposed by Stiglitz and Weiss, where lenders do not raise the rate of interest to clear the market when demand for funds exceeds supply, because to do this 
would screen out low return, low risk developers, and so deleteriously effect the quality of the loan portfolio.

There is therefore a theoretical rationale for believing that there may be a positive risk-return relationship for land development without government intervention. The effect of tax concessions and subsidies to brownfield development will be to exacerbate this positive relationship and increase the likelihood of credit rationing during boom periods. As a result, the concavity of the supply curve may be reinforced by the rationing of credit. This, in effect, induces an upper ceiling on quantity of construction: irrespective of the interest rate developers would be willing to pay, lenders will not increase the supply of credit, and may even lead to a situation where credit is reduced.

\section{Credit Market Implications of Quotas}

Quotas could also have unintended adverse effects, depending on their implementation. If the government simply restricts the number of greenfield sites available for development, then a larger proportion of loan applications will be for brownfield development, and this will simply serve to raise the pooled interest rate (because the average risk of loan default is higher) or cause further credit rationing.

If there is a tax concession to brownfield land in addition to the greenfield quotas, then the quota will exacerbate the moral hazard from raising interest rates and increase the extent of credit rationing. Moreover, if quotas are unequally binding across regions, the resulting heterogeneity may cause credit rationing without 
government subsidisation of brownfield, and exacerbate the concavity/backwardbending characteristic of the new construction supply curve, as explained above.

\section{Alternative Solutions}

If the above theoretical arguments prove to have an important real-life impact on housing construction, then provision of public housing on brownfield sites may prove to be a more attractive alternative. The possibility that intervention by subsidy may induce 'brownfield credit rationing' of sufficient potency to counteract the benefits of the policy, implies that for a subsidy/tax concession program to be effective, it may have to be substantial. And a substantial subsidy or loss of tax revenue would then have to be weighed against the cost of direct provision through building public housing on brownfield sites.

Such a policy is not without its problems, however, since it incurs an ethical dilemma for policy makers. Its corollary is that the state would be deliberately building social housing on land with above average risk of contamination. Now if public housing tenure were scattered randomly across all strata of society (delineated by income, sex, race, family structure) then the social justice objections would be minimal. Since, however, in the UK and many other countries, public housing tenants tend to be at the lower end of the income scale, the building of public housing on brownfield land would constitute a decision to place the burden of contamination risk squarely on the shoulders of the economically/socially disadvantaged. This would be ethically unacceptable. 
Another alternative would be for the state itself to bear the burden of moral hazard and directly provide loans for brownfield development. If such loans were competitively priced, ${ }^{4}$ so that it would be more advantageous for developers of brownfield land to seek public finance, then this policy would have the added benefit of reducing the proportion of brownfield projects for which developers seek private finance, and so reduce the average risk associated with the loan books of private lending institutions. The likely consequence would be to reduce the rate of interest generally charged on private finance to the construction industry. To ensure no adverse intended consequences, however, public loans to brownfield developers would have to cover the total credit requirement of the projects concerned, otherwise the loans may have the effect of encouraging more brownfield applications for private finance, albeit for part, rather than total, funding of brownfield projects.

Perhaps a more politically feasible solution would be the state provision of insurance against contamination risk. There is a precedent for the state to provide insurance to profit-making market agents for the ultimate good of society in the form of the UK's Loan Guarantee Scheme (LGS) introduced in 1981 to improve access to credit by small firms constrained in their ability to borrow by lack of collateral. Firms pay an insurance premium - calculated as a proportion of the loan - to the government, and in the event of default, the state compensates the bank for the outstanding amount of the proportion guaranteed. ${ }^{5}$ Since the main goal of brownfield indemnification would be

\footnotetext{
${ }^{4}$ Issuing loans at rates below those offered by the market may not require massive subsidies because governments can in principle borrow funds from international money markets at rates below those of the private sector (in principle, governments cannot go bankrupt and so are charged a lower risk premium). Also, government departments are not subject to the same profit requirements as private lending institutions.

${ }^{5}$ Premiums would have to be set at an appropriate level, however. Cowling (1995) found take up rates to be highly contingent on guarantee and premium parameters, which have had at least three sets of
} 
to place some bound to the uncertainties of decontamination costs rather than covering all potential losses, the state scheme could include a substantial excess requirement and still be effective.

The question, however, regarding the appropriateness of such a policy, is why the market does not provide contamination insurance. State provision of insurance could subsequently be accused of 'crowding out' private insurance (a comparable, but somewhat eroneous claim, was made by the Conservative Government regarding ISMI [Income Support for Mortgage Interest] and MPPI [Mortgage Payment Protection Insurance] - see Pryce 2002). Actually, a market in remediation insurance does appear to be emerging as adverts in trade magazines (Rodway 2001) and on the web (Nathanson 1999; Amos 2002) testify. However, there are likely to be limits and exclusions to such policies and so the case for government intervention may remain (analogous again to the ISMI-MPPI debate).

Finally, the state could reduce the uncertainties associated with contamination by financing and organising the decontamination itself. This appears to be emerging by default as the solution in a number of countries. With respect to the United States, for example, McGrath (2000) notes that,

'The general view is that the current federal and state regulatory requirements regarding remediation of any discovered contamination places substantial legal and financial barriers to the redevelopment of urban industrial land. This is believed to be one of the forces contributing to employment deconcentration and to the acceleration of industrial development at the urban fringe of our metropolitan areas. This view has prompted municipal officials to begin to take on the financial responsibility for the remediation of contaminated industrial properties; the belief is that this public investment will make the

values since inception. From June 1981 to May 1984, premiums and guarantees rates were 3\% and $80 \%$ of the loan value respectively. These rates became $5 \%$ and $70 \%$ in June $1984 ; 2.5 \%$ and $70 \%$ in April 1986; and 1.5\% and 85\% in 1993 (Cowling 1995). 
central city more competitive in attracting industrial users for these properties." (McGrath, 2000, p. 414-415).

Similar views are presented by Rodenburg et al (2000) who argue strongly for the prominent role of the state in soil remediation in the context of the Netherlands. Indeed, from the point of view of economic theory (as presented in this paper at least), if the governments want to encourage brownfield development, without risk of dampening supply overall, then this would be a safe, if expensive, option. How realistic it is as a solution in countries such as the UK with considerable quantities of contaminated land concentrated in particular cities is questionable, however, and one would again have to consider the opportunity costs of widely adopting such an approach.

\section{Conclusion}

Central to the housing and environmental sustainability debate in post-industrial economies is the redevelopment of brownfield land. The assumed solution over the past decade has been that of land use planning. Markets have been relegated irretrievably to being part of the problem, precluding their role in any possible remedy. This paper has reflected on the variety of explanations put forward for why the market apparently fails to adequately utilise brownfield land, and has found some of these causes to have their root in the state itself. I have also presented a previously overlooked possible cause of under-investment in brownfields: the impact of asymmetric information on credit markets for residential construction. I then considered state failures in the allocation of land and the likely impact of information problems on the success of fiscal measures to encourage brownfield development. This discussion led naturally to the conclusion that the current focus of government 
policy on fiscal intervention is unlikely to achieve a substantial transition to brownfield development without having a significant negative effect on the supply of housing overall. Government intervention of this kind runs the risk of exacerbating the uncertainty and capital market distortions associated with brownfield development whilst having little positive direct impact on supply decisions.

In considering the issues raised above, I believe that the paper has also helped to link the state failure and equilibrium credit rationing literatures and, in so doing, helped to identify a previously overlooked category of state failure. Although considerable attention has been given to the explanation of credit rationing and its ramifications for the macro economy, they have not been applied to the analysis of fiscal policy, which I think this paper has shown, can lead to interesting insights. I have attempted to demonstrate that policies aimed at encouraging development on brownfield sites may create/exacerbate the positive relationship between risk and return on construction projects and deepen the moral hazard/adverse selection problems faced by lenders. Their logical response will be to ration credit to all developers or increase credit restrictions to certain development types.

Of the extent to which there exist parallels of this new species of state failure elsewhere in public policy, and hence of its generalisability, I am not certain. Usually governments encourage their subjects to behave in a less risky fashion, and perhaps the provision of fiscal incentives for brownfield development is a unique example of the opposite. As it is, the insight adds to a long list of examples of state failure in planning and strengthens the case for reconsidering alternative means of addressing the problems of brownfield development and environmental sustainability more 
generally. The discussion presented in this paper does not lead easily to the conclusion that the state should not intervene altogether but to a consideration of involvement other than through land planning and fiscal intervention which have particularly adverse effects on the supply of housing overall. The state may well have a legitimate role as insurer or as a direct provider of decontamination.

I have, however, only scratched the surface of potential alternative solutions. There is much scope for future research, both empirical and theoretical, into policies that can be deployed in a less heavy-handed way than those currently in vogue. This paper has attempted to provide a conceptual framework for understanding the link between such policies and the financial sector; one that I hope will serve to broaden the debate on housing and environmental sustainability and foster more careful consideration of the economic consequences of proposed solutions.

\section{References}

Adams, D., Disberry, A., and Hutchison, N. (1999) 'Taxes, Subsidies and the Behaviour of Brownfield Owners' 6th European Real Estate Society Conference, Athens

Adams, D., Disberry, A., Hutchison, N., and Munjoma, T. (2001) 'Ownership constraints to brownfield redevelopment', Envirnonment and Planning A $33[3], 453-477$

Amos, B. (2002) “The Role of Insurance in Brownfields Redevelopment", Advert on the web for ECS Inc, http://www.cleanstart.com/report2.htm. 
Baachetta, P. and Caminal, R. (1996). 'Do Capital Market Imperfections Exacerbate Output Fluctuations?' (Centre for Economic Policy Research, Discussion Paper 1422: London.)

Ball, M., Lizieri,C., and Macgregor, B. (1998) 'The Economics of Commercial Property Markets', Routledge, London.

Bartlett, W. (1989) 'Housing Supply Elasticities - Theory and Measurement', JRF Discussion Papers, Housing Finance Series.

Bernanke, B. S. (1983). Nonmonetary effects of the financial crisis in the propagation of the Great Depression. American Economic Review, 73, 257-276.

Bond, S.G. (2001a) 'The use of conjoint analysis to assess the impact of environmental stigma,' Pacific Rim Property Research Journal, Vol.7, No.3, 2001.

Bond, S.G. (2001b) 'Stigma assessment: The case of a remediated contaminated site,' Journal of Property Investment and Finance, Vol. 19, No.2, pp. 188-210.

Bond, S.G., Kinnard, W.N., Kennedy, P.J., \& Worzala, E.M. (2001) 'An international perspective on incorporating risk in the valuation of contaminated land,' The Appraisal Journal, July, pp.258-265.

Bradbury, K. et al (1977) Simultaneous Estimation of the Supply and Demand for Housing Location in a Multizoned Metropolitan Area, in Ingram, G. K. (ed), 1977, Residential Location and Urban Housing Markets, NEBR: NY, pp. 5192.

Bramley, G (1993a) 'The Impact Of Land-Use Planning And Tax Subsidies On The Supply And Price Of Housing In Britain', Urban Studies, 30, No- 1, Pg- 5-30. 
Bramley, G (1993b) Land-Use Planning And The Housing-Market In Britain - The Impact On Housebuilding And House Prices, Environment \& Planning A, 25, 7, 1021-1051

Bramley, G. (1996) Impact Of Land-Use Planning On The Supply And Price Of Housing In Britain: Reply to Comment by Alan W. Evans, Urban Studies, 33, No- 9, Pg- 1733-1737.

Cadman, D. and Topping, R. (1995) 'Property Development', $4^{\text {th }}$ Edition, E and F Spon: London, p.150.

Carruth, A. and Henley, A. (1990) Can Existing Consumption Functions Forecast Consumer Spending in the late 1980s?, Oxford Bulletin of Economics and Statistics, Vol 52, No 2, pp 211-222

Chesire, P. and Sheppard, S. (1989) British Planning Policy and Access to Housing: Some Empirical Estimates, Urban Studies 26, 469-485

Chesire, P. and Sheppard, S. (1997) 'The Welfare Economics of Land Use Regulation'. Research Papers in Environmental and Spatial Analysis 42. Department of Geography: London School of Economics and Political Science.

Cowling, M. (1995) 'Initial tests on the sensitivity of the parameters of the UK Loan Guarantee Scheme', Public Finance 50, 356-370.

DETR (1998) "Planning for the Communities of the Future", Department of the Environment, Transport and the Regions, London, February 1998.

Engle, R. (2001) “GARCH 101: The Use of ARCH/GARCH Models in Applied Econometrics", Journal of Economic Perspectives, 15, 4, pp. 157-168. 
Ermisch, J., Findlay, J., and Gibb, K. (1996) 'The Price Elasticity of Housing Demand in Britain: Issues of Sample Selection' Journal of Housing Economics 5, 6486.

Evans, A. (1985). 'Urban Economics' (Blackwell: Oxford.)

Evans, A. (1987). 'House Prices and Land Prices in the South East: A Review' (House Builders Federation: London.)

Evans, A. (1988). 'No Room, No Room!' (Institute of Economic Affairs, Occasional Paper No. 79: London.)

Evans, A. (1991) 'Rabbit Hutches on Postage Stamps: Planning, Development and Political Economy' Urban Studies 28[6], 853-870.

Evans, A. W. (1996) The Impact Of Land-Use Planning And Tax Subsidies On The Supply And Price Of Housing In Britain, Urban Studies, Vol. 33, No. 3, 581585.

Hardin, G. (1968) "The Tragedy of the Commons," Science, 162:1243-1248.

Kemp, P., Lynch, E., and Mackay, D. (2001). 'Structural Trends and Homelessness: A Quantitative Analysis' (Scottish Executive: Edinburgh.)

King, M. A. (1980) 'An Econometric Model of Tenure Choice and Demand for Housing as a Joint Decision' Journal of Public Economics 14, 137-159.

Kinnard, W. N., Jr. (1996) 'Evolving Attitudes and Policies of Institutional Investors and Lenders toward On-Site and Nearby Property Contamination', paper presented at the 12th Annual Meeting of the American Real Estate Society. 
KPMG (1999) 'Fiscal Incentives for Urban Housing: Exploring the Options' (Urban Task Force, Department of the Environment, Transport and the Regions: London.)

Maclennan, D. (1994) 'Competitive UK Economy' Joseph Rowntree Foundation: York.

Mayes, D. (1979) The Property Boom: The Effects of Building Society Behaviour on House Prices, Oxford: Martin Robertson.

Mayo, S. and Sheppard, S. (1991) Housing Supply and the Effects of Stochastic Development Control, Oberlin Discussion Paper in Economics, Oberlin University, USA.

McGrath, D. T. (2000) 'Urban Industrial Land Redevelopment and Contamination Risk', Journal of Urban Economics, 47, 414-442.

Meen, G. (1998) ‘Modelling Sustainable Home Ownership: Demographics or Economics?' Urban Studies 35[11], 1919-1934.

Muth, R. (1960) The demand for non-farm housing, in Harberger, A. (ed.), The Demand for Durable Goods, the University of Chicago Press, Chicago.

Muth, R. (1964) The derived demand for a productive factor and the industry supply curve, Oxford Economic Papers, 16:221-34

Muth, R. (1969) Cities and Housing, Chicago: University of Chicago Press.

Muth, R. (1971) The derived demand for urban residential land, Urban Studies, $8: 243-54$

Nathanson, G. A. (1999) “Environmental Contamination And Pollution Insurance”, Building Business \& Apartment Management (April 1999), publication of the 
Building Industry Association of Southeastern Michigan, reprinted as part of an advert on the web: http://www.couzens.com/pubs/insurance.shtml

Needham, B. (2000) 'Land taxation, development charges, and the effects on land use', Journal of Property Research, 17(3), 241-257.

Olsen, E. O. (1987) The Demand and Supply of Housing Services, a Critical Survey of the empirical literature, in Mills, E. S. (ed) Handbook of Regional and Urban Economics, Vol. II, Amsterdam: North Holland, pp. 989-1022.

Ozanne, A. (1996) 'Do Supply Curves Slope Up? The Empirical Relevance of the Sraffian Critique of Neoclassical Production Economics', Cambridge Journal of Economics, Vol 20, pp. 749-762.

Parker, S. C. (2002) 'Do Banks Ration Credit to New Enterprises? And Should Governments Intervene?', Scottish Journal of Political Economy, 49, 2, 162195.

Patchin, P J. (1988) 'Valuation of Contaminated Property', Appraisal Journal, January, 7-16.

Pennington, M. (1997a) 'Budgets, Bureaucrats and the Contaniment of Urban England' Environmental Politics, 6[4], 76-107.

Pennington, M. (1997b). 'Property Rights, Public Choice and the Containment of Urban England,' Unpublished PhD Thesis Edn., London School of Economics and Political Science: London.

Pennington, M. (1999) 'Free Market Environmentalism and the Limits of Land Use Planning', Journal of Environmental Policy and Planning 1[1], 43-59.

Pennington, M. (2000). 'Planning and the Political Market: Public Choice and the Politics of Government Failure,' Athlone Press: London. 
Pryce, G. (1999a) 'Construction Elasticities and Land Availability: A Two Stage Least Squares Model of Housing Supply Using the Variable Elasticity Approach', Urban Studies, 36, 13, 2283-2304.

Pryce, G. (1999b) 'Assessing, Perceiving and Insuring Credit Risk', unpublished $\mathrm{PhD}$ thesis, University of Glasgow: Glasgow.

Pryce, G. (2001) 'Cycles In The Price Elasticity Of Demand For Housing’, Ecofin Discussion Paper 5, Department of Urban Studies, University of Glasgow Pryce, G. (2002) 'Theory and Estimation of the Mortgage Payment Protection Insurance Decision', Scottish Journal of Political Economy, 49, 2, 216-234.

Quigley, J. M. and Raphael, S. (2001) 'The Economics of Homelessness: Evidence from North America,' European Journal of Housing Policy 1[3], 323-336..

Rodenburg, C., Nijkamp, P. and Wagtendonk, A. J. (2000) “Success Factors for Urban Brownfield Development: A Comparative Case Study Approach to Polluted Sites", RSAI World Congress May 2000, Lugano, Switzerland.

Rodway, S. (2001) “Insuring Success”, Advert for Argyll Environmental Risk Services in Sustain Focus, 02, 04 p. 57

Schmidt, P. (1976) Econometrics, New York: Marcel Dekker.

Shea, J. (1993) ‘Do Supply Curves Slope Up?’ Quarterly Journal of Economics, CVIII, pp. 1-32.

Sirmans, C. F. and Redman, A. L. (1979) 'Capital-land substitution and the price elasticity of demand for urban residential land' Land Economics 55[167], 176.

Stiglitz, J. E. and Weiss, A. (1981) 'Credit rationing in markets with imperfect information' American Economic Review 71, 393-411. 
Stiglitz, J. E. (1999) 'Interest rates, risk, and imperfect markets: Puzzles and policies', Oxford Review of Economic Policy 15[2], 59-76.

Titman, S. (1985) ‘Urban land prices under uncertainty’, American Economic Review, 75 , pp. 505-514.

Weber, B.R. (1997) “The Valuation of Contaminated Land”, Journal of Real Estate Research, 14, 3, pp.379-398.

Whitehead, C. (1974) The UK Housing Market, Farnborough: Saxon House. 